\title{
Sequence Data for Two Large-Subunit rRNA Genes from an Asian Strain of Alexandrium catenella
}

\author{
P. K. K. YEUNG, K. F. KONG, F. T. W. WONG, \\ AND J. T. Y. WONG* \\ Department of Biology, Hong Kong University of Science and Technology, \\ Clear Water Bay, Kowloon, Hong Kong
}

Received 25 July 1996/Accepted 14 August 1996

\begin{abstract}
PCR generated two distinct products from a toxic isolate of Alexandrium catenella, which had been taken from Dai Ya Bay (southern China), by using primers for large-subunit rRNA. This pattern is distinct from published data for North American Alexandrium species. Sequences of the two products suggest that the smaller was generated by a deletion event. Single-cell PCR generated the same pattern, confirming that the two products were not the results from different individuals.
\end{abstract}

Many dinoflagellate species belonging to the genus Alexandrium (= Protogonyaulax Taylor [12]) are among the most common agents of red tides. These globally distributed species have many similarities in morphology. Monoclonal antibodies, isozymes, and fluorescent characters have been employed for species detection and differentiation $(1,2,6)$. An elegant protocol incorporating both PCR and restriction fragment length polymorphism has been developed to distinguish some of the toxic and nontoxic strains of Asian, European, and North American species of Alexandrium $(3,7,8)$. Partial sequences of both large- and small-subunit rRNA genes were also used to develop molecular markers for different species and strains of the genus Alexandrium (7).

Abbreviations. The following abbreviations are used in this paper: CCMP, Provasoli-Guillard Culture Center for Marine Phytoplankton; PCC, Plymouth Culture Collection; LsurRNA, large-subunit ribosomal RNA.

The present study aimed to provide sequence data for an Alexandrium catenella isolate (CCMP1493) from Dai Ya Bay. This strain of $A$. catenella was obtained from CCMP and was propagated as recommended by the CCMP. DNA extraction was carried out by a modified hexadecyl trimethylammonium bromide method (13). The PCR primers used were based upon the LsurRNA sequence data of Protocentrum micans (4). The

$\mathbf{A}$

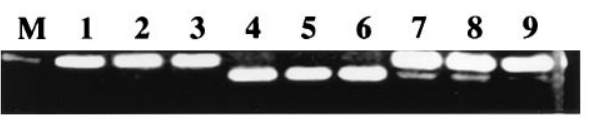

B

\begin{tabular}{ccccccc}
$M$ & 1 & 2 & 3 & 4 & 5 & 6 \\
\hline & & & & & & \\
\hline
\end{tabular}

FIG. 1. (A) PCR products generated by using rRNA primers. Templates are as follows: lanes 1 to $3, A$. (Gonyaulax) tamarensis PCC173; lanes 4 to $6, A$. carterae PCC450; lanes 7 to 9, A. catenella CCMP1493. For each species PCR was carried out at a different annealing temperature: $A$. tamarensis, $56^{\circ} \mathrm{C} ; A$. carterae, $48^{\circ} \mathrm{C}$; and $A$. catenella, $42^{\circ} \mathrm{C}$. (B) Single-cell PCR of CCMP1493. Only the results for six individuals are shown. M, 700-bp DNA size marker.

\footnotetext{
* Corresponding author
}

same primers had been used to study the LsurRNA gene sequence data of the Alexandrium species complex (3, 7-9). The forward and reverse primers were D1R (ACCCGCTGAATT TAAGCATA) and D2C (CCTTGGTCCGTGTTTCAAG), respectively. PCR was carried out with Taq polymerase (Perkin-Elmer Corporation) and involved 30 cycles of amplification

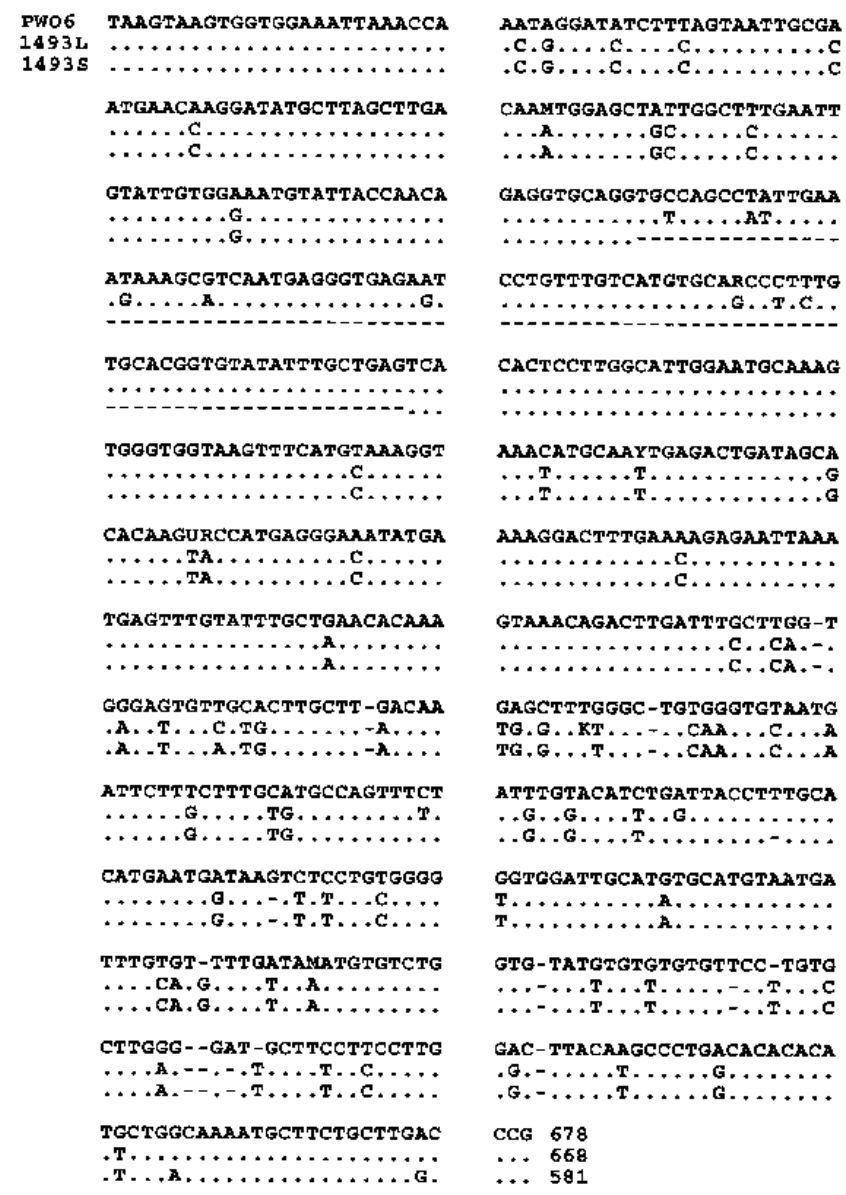

FIG. 2. Sequence of the cloned LsurRNA genes. The sequence for P. micans (PW06) is from reference 4. L and S denote the large and small PCR products of CCMP1493. Dots represent identical bases. 


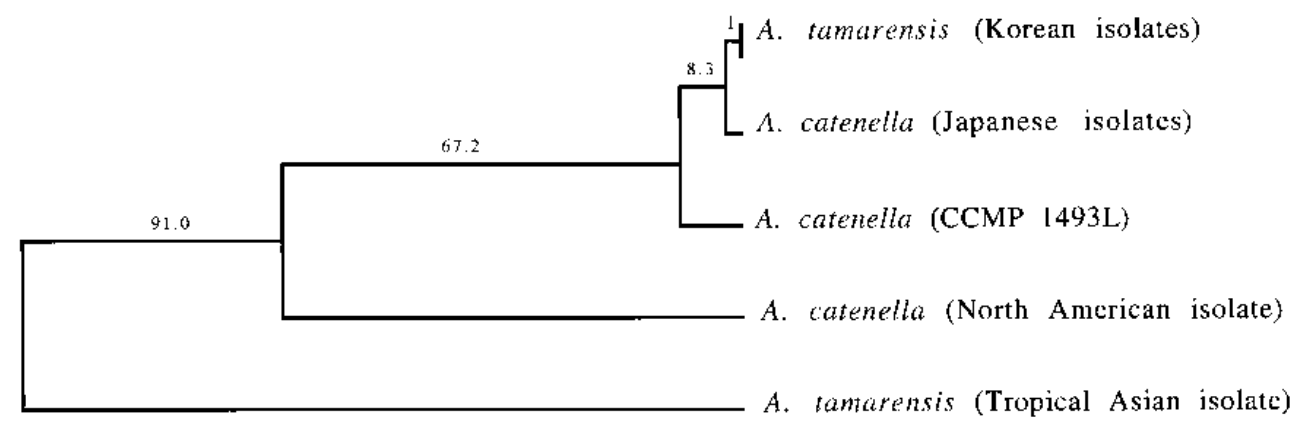

FIG. 3. Phylogenetic tree of Alexandrium spp. constructed by using the unweighted pair group method with arithmetic averages. Numbers denote the average number of sequence differences, in base pairs. Aside from CCMP1493 sequence data, sequence data were adapted from reference 10. Korean isolates of $A$. tamarensis were G.Hope 1 and G.Hope 2; Japanese isolates of $A$. catenella were OF101, TN9, WKS-8, ACPP01, ACPP02, ACPP03, and G.Crux; the North American isolate of A. catenella was BGt1; the tropical Asian isolate of $A$. tamarensis was CU-13. The sequences of the Japanese and Korean isolates were pooled into two groups since there was at most a 1-bp difference between the sequences of the isolates of each group.

with the Stratagene Robocycler II. Unless stated otherwise, the denaturing step was carried out at $94^{\circ} \mathrm{C}$ for $1 \mathrm{~min}$, the annealing step was carried out for $90 \mathrm{~s}$ at $48^{\circ} \mathrm{C}$, and the extension step was carried out for $30 \mathrm{~s}$ at $72^{\circ} \mathrm{C}$. The PCR products were cloned with the TA cloning kit (Invitrogen Corporation) and sequenced by the AutoRead system (Pharmacia Corporation). Each sequence reported here represents the cumulative results of at least two separate sequencing reactions from each of three separate clones.

As observed for other species of the Alexandrium genus, a single amplified product of about 700 bp was observed for Alexandrium tamarensis PCC173 and Amphidinium carterae PCC450. However, two amplified products were observed for CCMP1493 (Fig. 1A). The major product had an apparent size identical to that of PCC173. An additional product with a smaller apparent size and less intensity was also observed. Sequence data suggested that the larger product was indeed the 668-bp band observed for other species of the genus. The smaller band has a 87-bp deletion from the major band. Aside from the deleted $87 \mathrm{bp}$, the smaller product has a 6-bp difference from the larger band. The sequences of both the larger and the smaller products are listed in Fig. 2. The presence of two PCR products with LsurRNA gene sequences suggests the presence of two distinct LsurRNA genes or the presence of a pseudogene. Two distinct small-subunit rRNA genes are present in Alexandrium fundyense (9), A. tamarensis, and $A$. catenella (8). According to the CCMP, CCMP1493 was isolated from cysts and may not be a monogenic strain. In order to examine the possibility that the two products were not amplified from different individuals, we performed single-cell PCR with CCMP1493. Dinoflagellates $(n>20)$ were microscopically separated from a CCMP1493 culture by using fine plastic pipette tips. The number of dinoflagellates in each pipette tip was confirmed microscopically by at least two persons. Only pipette tips containing one dinoflagellate were used for PCR. The supernatant was carefully decanted after the cell was spun down in a PCR tube. The PCR mixture was immediately added, and PCR was performed as described earlier. The resulting PCR products from individual CCMP1493 cells (Fig. 1B) consisted of the two bands reported earlier. PCR with pipette tips that captured medium but no dinoflagellates generated no observable bands (data not shown). This suggested that the observed PCR products were not a result of the possible polygenic nature of CCMP1493.

LsurRNA gene sequence data from a previous study suggested that the Alexandrium species complex was indeed a heterogeneous group (10). Interestingly, any morphological similarities were not confirmed by sequence similarities. The Japanese isolates of $A$. catenella were more closely affiliated with the Korean isolates of $A$. tamarensis than to $A$. catenella isolates from western North America. However, the Japanese isolates were suspected of having been artificially transferred from Australia. In the present study, the LsurRNA gene sequence of CCMP1493 has a 9- or 10-bp difference from those of the Japanese isolates of $A$. catenella and the Korean isolates of $A$. tamarensis, which is much larger than the 0- to 2-bp differences between the Japanese and Korean isolates themselves. Similar to the previous study, it also has a larger difference $(80 \mathrm{bp}$ ) from those of the western North American isolates of $A$. catenella and the tropical Asian isolates of $A$. tamarensis. The numbers of sequence differences between the 668-bp PCR product and products from the other isolates were used to generate a phylogenetic tree by using the unweighted pair group method with arithmetic overages (Fig. 3). CCMP1493 has a phylogenetic position between the Japanese and Korean isolates of Alexandrium on the one hand and the western North American isolate of $A$. catenella on the other.

In southern China, where CCMP1493 was isolated, several human fatalities occurred in recent years as a result of paralytic shellfish poisoning (5). The sequence data generated for CCMP1493 should be useful for the design of species-specific probes for use in the molecular detection of this toxic strain. Fluorescence-labeled oligonucleotide probes for specific sequences of dinoflagellate rRNA have been proven to detect dinoflagellates quantitatively by flow cytometry (11).

Nucleotide sequence accession number. The sequence obtained in this study has been assigned GenBank accession number U64434.

\section{REFERENCES}

1. Cembella, A. D., and F. J. R. Taylor. 1987. Electrophoretic variation within the Protogonyaulax tamarensis/catenella species complex: pyridine linked dehydrogenases. Biochem. Syst. Ecol. 14:311-323.

2. Costas, E., and V. L. Rodas. 1994. Identification of marine dinoflagellates using fluorescent lectins. J. Phycol. 30:987-990.

3. Judge, B. S., C. A. Scholin, and D. M. Anderson. 1993. RFLP analysis of a fragment of the large-subunit ribosomal RNA gene of globally distributed populations of the toxic dinoflagellate Alexandrium. Biol. Bull. 185:329-330.

4. Lenaers, G., C. Scholin, Y. Bhaud, D. Saint-Hilaire, and M. Herzog. 1991. A molecular phylogeny of dinoflagellate protists (Pyrrhophyta) inferred from the sequence of $24 \mathrm{~S}$ rRNA divergent domains D1 and D8. J. Mol. Evol. 32:53-63.

5. Lin, Y., M. Yang, R. Chen, S. Hu, and G. Quan. 1994. Paralytic shellfish poisoning from the coast of Guangdong. South China Sea Fish. Res. 1994: $16-20$.

6. Sako, Y., M. Adachi, and Y. Ishida. 1993. Preparation and characterisation 
of monoclonal antibodies to Alexandrium species, p. 87-93. In T. J. Smayda, and T. Shimizu (ed.), Toxic phytoplankton blooms in the sea. Elsevier, New York.

7. Scholin, C. A., and D. M. Anderson. 1994. Population analysis of toxic and non-toxic Alexandrium species using ribosomal RNA signature sequences, p. 5-102. In T. J. Smayda and T. Shimizu (ed.), Toxic phytoplankton blooms in the sea. Elsevier, New York.

8. Scholin, C. A., and D. M. Anderson. 1994. Identification of group- and strain-specific genetic markers for globally distributed Alexandrium (Dinophyceae). I. RFLP analysis of SSU rRNA genes. J. Phycol. 30:744-754.

9. Scholin, C. A., D. M. Anderson, and M. Sogin. 1993. The existence of two distinctive small-subunit rRNA genes in the toxic dinoflagellate Alexandrium fundyene (Dinophyceae). J. Phycol. 29:209-216.

10. Scholin, C. A., M. Herzog, M. Sogin, and D. M. Anderson. 1994. Identifica- tion of group- and strain-specific genetic markers for globally distributed Alexandrium (Dinophyceae). II. Sequence analysis of a fragment of the LSU rRNA gene. J. Phycol. 30:999-1011.

11. Simon, N., N. LeBot, D. Marie, F. Partensky, and D. Vaulot. 1995. Fluorescent in situ hybridization with rRNA-targeted oligonucleotide probes to identify small phytoplankton by flow cytometry. Appl. Environ. Microbiol. 61:2506-2513.

12. Steidinger, K. A., and Ø. Moestrup. 1990. The taxonomy of Gonyaulax, Pyrodinium, Alexandrium, Gessnerium, Protogonyaulax and Goniodoma, p. 522-523. In E. Graneli, B. Sundstrom, L. Elder, and D. M. Anderson (ed.), Toxic marine phytoplankton. Elsevier, New York.

13. Winnepenninckx, B., T. Backeljau, and R. DeWachter. 1993. Extraction of high molecular weight DNA from mollusc. Trends Genet. 9:407. 